\title{
COLLECTIEVE VERANTWOORDELIJKHEID VAN SAMENWERKENDE ACCOUNTANTS
}

\author{
door Drs J. Vogel
}

Het is wellicht doelmatig aan een behandeling van het vraagstuk der $z g n$. collectieve verantwoordelijkheid een begripsbepaling te doen voorafgaan. Uit discussies in vakkringen en uit publicaties is mij bekend, dat wij onder ",verantwoordelijkheid" of ",vaktechnische verantwoordelijkheid" gewoonlijk verstaan de verantwoordelijkheid, welke de accountant draagt voor een juiste wijze van beroepsuitoefening, zoals deze hem wordt voorgeschreven - behalve uiteraard door algemene ethische normen - door de reglementen van de vereniging, waarbij hij is aangesloten.

Indien men de civielrechtelijke verantwoordelijkheid bedoelt, wordt ter onderscheid gewoonlijk het woord ,,aansprakelijkheid" gebezigd. Ik ben door een jurist opmerkzaam gemaakt op het feit dat taalkundig de woorden verantwoordelijkheid en aansprakelijkheid als synoniem zijn te beschouwen, zulks onder verwijzing naar van Dale. Men zal er daarom m.i. goed aan doen, vooral indien over dit onderwerp wordt gepubliceerd of wordt gediscussieerd met niet-collega's, uitdrukkelijk te stellen dat met ",accountants-verantwoordelijkheid" of „,vaktechnische verantwoordelijkheid" wordt bedoeld de tuchtrechtelijke verantwoordelijkheid of zo men wil de tuchtrechtelijke aansprakelijkheid.

Indien ik in de volgende regelen schrijf over collectieve verantwoordelijkheid van samenwerkende accountants wordt daarmede bedoeld de omstandigheid, dat voor een overtreding begaan tegen de beroepsreglementen van de vereniging, waarvan een accountant lid is, niet slechts de betrokken accountant doch ook de collega's waarmede hij in maatschap of op andere wijze samenwerkt ter verantwoording geroepen kunnen worden voor de tuchtinstantie der vereniging.

Voor zover mij bekend is, is het Nederlands Instituut van Accountants de enige accountantsvereniging in ons land, die in haar reglementen bepalingen heeft opgenomen, welke op de $\mathrm{zgn}$. collectieve verantwoordelijkheid betrekking hebben. Ik heb met opzet gesteld de „.zgn." collectieve verantwoordelijkheid, want in feite is er nimmer een andere dan een individuele verantwoordelijkheid mogelijk.

Immers de vereniging kent slechts individuele accountants als lid en slechts tegen leden kan door de tuchtinstantie worden opgetreden. Men heeft daarom de desbetreffende bepalingen moeten formuleren als verplichtingen waaraan de individuele leden moeten voldoen om niet het risico te lopen met de tuchtrechtspraak in aanraking te komen.

Een en ander is geregeld in artikel 4 van het Reglement van Arbeid. van welk artikel ik hier de tekst laat volgen:

\section{Artikel 4.}

1. Een lid, dat de practijk uitoefent in maatschap met een ander lid, is verplicht zodanige voorzieningen te treffen, dat hij zich in redelijkheid overtuigd kan houden, dat de arbeid van zijn medevennoot en diens mededelingen omtrent de uitkomsten van onderzoekingen voldoen aan de bepalingen van dit reglement. Deze verplichting strekt zich niet verder uit dan de algemene grondslagen van de onderzoekingen.

2. Onder algemene grondslagen van de onderzoekingen worden verstaan

m a b blz. 252 
zowel de algemene beginselen, vastgesteld in de reglementen van het Nederlands Instituut van Accountants als de beginselen volgens welke de werkprogramma's voor de onderzoekingen van de maatschap worden opgesteld.

3. Een overeenkomstige verplichting rust op de leden, die hun practijk uitoefenen met gebruik van een gemeenschappelijke naam.

4. Een overeenkomstige verplichting rust op de leden, die hun practijk uitoefenen met bijstand van of in samenwerking met een ander lid. ten aanzien van de arbeid en de mededelingen van dat lid.

De strekking van dit artikel is - ondanks de beperking tot de in lid 2 nader omschreven algemene grondslagen - duidelijk. Hier wordt voorgeschreven, dat de leden zich ervan moeten overtuigen dat de wijze waarop het accountantsberoep wordt uitgeoefend door medevennoten, gemeenschappelijke-naam-gebruikers en medewerkers voldoet aan de bepalingen van het Reglement van Arbeid. (,Zodanige voorzieningen treffen, dat men zich in redelijkheid overtuigd kan houden" acht ik een zeer waterige formulering van ,zich overtuigen". Immers indien de overtuiging niet gerechtvaardigd zou blijken zijn de voorzieningen niet deugdelijk geweest).

Hoe dit echter ook zij, het Reglement van Arbeid opent de mogelijkheid, dat accountants verantwoordelijk worden gesteld voor het zich niet voldoende overtuigen van de juiste wijze van beroepsuitoefening door medevennoten. (De andere categorieën laat ik verder ongenoemd, doch daarvoor gelden mijn beschouwingen mutatis mutandis eveneens).

De gedachte welke aan deze bepaling ten grondslag ligt kan naar mijn mening geen andere zijn dan dat accountants die gezamenlijk naar buiten optreden ook collectief voor dit optreden verantwoordelijk zijn.

De vragen welke nu beantwoord moeten worden zijn:

1. Wanneer moet aangenomen worden, dat de accountants gezamenlijk naar buiten optreden.

2. Is het gewenst, dat in gevallen, waarin accountants tengevolge van gezamenlijk optreden collectief verantwoordelijk behoren te zijn, deze collectieve verantwoordelijkheid door een reglement van arbeid wordt beperkt of uitgesloten.

3. Is het gewenst, dat in gevallen, waarin (geassocieerde) accountants niet gezamenlijk naar buiten optreden de collectieve verantwoordelijkheid door een reglement van arbeid wordt gecreëerd.

Bij de eerste vraag zou ik willen opmerken, dat in vele gevallen samenwerkende accountants zich naar buiten aandienen als accountantskantoor, rapporten en verklaringen stellen in de meervoudsstijl - alsof alle associé's in spreekkoor een verklaring afleggen - en in sommige gevallen zelfs zo ver gaan te tekenen met de maatschapsnaam.

Aan deze wijze van zich aandienen zijn n.m.m. inderdaad consequenties verbonden ten aanzien van de verantwoordelijkheid. Immers indien naar buiten in veel sterkere mate met de naam van de maatschap wordt gewerkt dan met de naam van de individuele accountant is het niet meer de accountant die het beroep uitoefent, doch is het het accountantskantoor dat de practijk uitoefent. Men kan dan niet eens meer spreken van de uitoefening van een beroep. Een beroep kan slechts door individuele per- 
sonen worden uitgeoefend. Zodra het accountantskantoor of de maatschap de practijk uitoefent wordt het bedrijfsoefening. In de termen van de "leer van het gewekte vertrouwen" uitgedrukt kan men zeggen dat dan niet de accountant is de vertrouwensman van het maatschappelijk verkeer, doch dat het accountantskantoor is de vertrouwensinstantie van het maatschappelijk verkeer.

Ik vermoed, dat de vraag of een beroep dan wel een bedrijf wordt uitgeoefend - een vraag waarop de accountant telkenjare bij de invulling van zijn belastingaangiftebiljet antwoord moet geven door de meeste collega's wordt beantwoord in die zin dat zij een beroep uitoefenen.

Met dit antwoord distanciëert men zich van de collectieve verantwoordelijkheid. Indien het de associatie is die de taak uitoefent, de verklaringen en rapporten afgeeft, het vertrouwen draagt, hetgeen de collectieve verantwoordelijkheid schept, dan is er bedrijfsuitoefening. Indien het de individuele accountant is, die de taak uitoefent, dan is er beroepsuitoefening maar dan is hij ook de man die met uitsluiting van anderen de verantwoordelijkheid draagt.

Over de vraag of een accountantsassociatie moest worden geacht een bedrijf uit te oefenen, zulks naar aanleiding van fiscale consequenties, heeft de Hoge Raad zich enkele malen uitgesproken. In een tweetal gevallen ${ }^{1}$ ) werd deze vraag bevestigend beantwoord. Niet uitgemaakt werd echter - en de Hoge Raad verklaarde, dat dit voor het desbetreffende geval niet nodig was - waar nu precies de grens lag tussen zelfstandig beroep en bedrijf. Ik meen, dat indien deze grens meer exact zou moeten worden getrokken daarbij van doorslaggevende betekenis zou kunnen zijn het al of niet dragen van collectieve verantwoordelijkheid door de in de associatie samenwerkende accountants. Of een beroep op artikel 4 van het Reglement van Arbeid voldoende zou zijn om deze collectieve verantwoordelijkheid vast te stellen waag ik niet te beoordelen, doch een aanwijzing in die richting is daarin toch zeker wel gelegen.

$\mathrm{Na}$ deze voorafgaande opmerkingen terugkerend tot de sub $1^{\circ}$ gestelde vraag: „wanneer moet aangenomen worden dat accountants gezamenlijk naar buiten optreden" meen ik, dat dit zeer zeker het geval is indien de uitgaande stukken met de maatschapsnaam worden getekend. I $\mathrm{k}$ meen dat dit echter niet het geval is, indien de uitgaande stukken gesteld worden in de enkelvoudsvorm en door de accountant met zijn eigen naam worden getekend. Dat dit dan gebeurt met vermelding van de maatschapsnaam in het briefhoofd of boven de handtekening heeft naar mijn mening niet tot gevolg dat het stuk geacht moet worden van de maatschap uit te gaan. Indien iemand schrijft: ,ik verklaar enz." en dat met zijn naam ondertekent valt daaruit toch bezwaarlijk te lezen, dat met de ondertekenaar nog anderen voor de juistheid van deze verklaring zouden instaan. Anders wordt dit echter wanneer er staat: „wij verklaren enz." met daaronder of in het briefhoofd de maatschapsnaam. Ook al tekent in dat geval één der leden van de maatschap met zijn eigen naam, dan nog kan een dergelijke verklaring worden gelezen als te zijn afgegeven door de maatschap namens welke één van de leden heeft getekend. In dit geval zou ik aan willen nemen dat de maatschap naar buiten optreedt in de accountantsfunctie. Er zijn wellicht nog meer mogelijkheden welke ik hier niet heb genoemd, doch de meest voorkomende vormen meen ik toch wel te hebben besproken en daarbij de opgeworpen vraag te hebben beantwoord.

\footnotetext{
1) Arrest van 21 Juni 1946 (B 8136) en arrest van 23 Januari 1952 (10810).
} 
Men kan mij tegenwerpen, dat het antwoord op deze vraag en dus ook het stellen van de vraag geen $z$ in heeft.

Men zou n.l. ook het standpunt kunnen innemen, dat zodra het publiek weet of kan weten, dat een accountant met een of meer collega's samenwerkt in maatschapsverband of op andere wijze, het er niet toe doet op welke wijze de accountant zich naar buiten aandient, omdat dan tegenover dit publiek onder alle omstandigheden de medevennoot mede de verantwoordelijkheid voor de wijze van beroepsuitoefening draagt, hetgeen in het Reglement van Arbeid tot uitdrukking dient te worden gebracht.

Ik ben het met dit standpunt niet eens. Het gaat m.i. niet aan om iemand een grotere verantwoordelijkheid of een andere verantwoordelijk heid op te leggen dan uit zijn eigen handelingen voortvloeit.

In het geval van de tekening met de maatschapsnaam of bij verklaringen in de wij-vorm vloeit die verantwoordelijkheid voort uit deze met onderling goedvinden gebruikte vorm.

Een „,verantwoordelijkheid" welke niet voortvloeit uit de eigen handeling kan ik niet erkennen en alleen reeds het hebben van associê's acht ik geen handeling waaruit vaktechnische verantwoordelijkheid voortvloeit, ook niet indien dit hebben van associé's uit briefhoofd of anderszins blijkt.

Komende aan de beantwoording van de sub $2^{\circ}$ gestelde vraag moet mijn antwoord ontkennend luiden. Indien een associatie als zodanig naar buiten optreedt dan dient de associatie in haar geheel volledig de verantwoordelijkheid te dragen. Er zou naar mijn mening niet een beperking tot de ,algemene grondslagen" in de bepalingen moeten voorkomen maar daarentegen wel een bepaling, dat ingeval een klacht wordt ingebracht tegen één van de leden ener als zodanig naar buiten optredende maatschap deze klacht geacht moet worden mede te zijn ingebracht tegen alle overige leden dier maatschap.

Op de vraag sub $3^{\circ}$ luidt mijn antwoord eveneens ontkennend. Ik acht het niet gewenst in gevallen waarin de samenwerkende accountants door hun optreden naar buiten er geen blijk van geven anders dan individueel te handelen niettemin ook de anderen verantwoordelijk te stellen voor het falen van één hunner.

Resumerende moet ik tot de conclusie komen, dat naar mijn oordeel artikel 4 óf te veel of te weinig geeft maar nooit de juiste maat.

Het is niet mijn bedoeling in dit opstel uitsluitend afbrekende critiek te leveren op de wijze waarop het vraagstuk van de collectieve verantwoordelijkheid in het Reglement van Arbeid werd geregeld. Naar mijn mening heeft men gepoogd met het oog open voor de nu eenmaal gegroeide gewoonte der Nederlandse accountantsassociaties zich als zodanig aan te dienen toch een zekere regeling te geven voor de verantwoordelijkheid welke de associé's voor elkaars arbeid dragen, doch men heeft daarbij naar mijn oordeel de fout gemaakt alle associaties over één kam te scheren.

Aan de verschillende wijzen waarop associaties zich plegen aan te dienen is geen recht gedaan. Naar mijn gevoelen waren hier afzonderlijke bepalingen nodig geweest voor accountants die hun individualiteit achter stellen bij de maatschap waaraan zij verbonden zijn en accountants die menen in de eerste plaats accountant en als zodanig zelfstandig beroepsuitoefenaar te zijn en dan dit beroep uitoefenen in maatschap met anderen, waarbij die maatschap de facto niet anders is dan ze ook de jure is: een overeenkomst tussen de betrokken partijen en geen lichaam met een eigen zelfstandigheid.

$\mathrm{ma} \mathrm{b}$ blz. 255 